$4^{\text {th }}$ International Conference on the Durability of Concrete Structures

24-26 July 2014

Purdue University, West Lafayette, IN, USA

\title{
Heavy Metal Desorption From Cement Hydrates Caused by Chloride Solutions
}

\author{
A. Hayashi, Y. Ogawa, and K. Kawai \\ Department of Civil and Environmental Engineering, Hiroshima University
}

\begin{abstract}
After the demolition of concrete structures, it is expected to recycle the whole of the demolished concrete. As of now, however, it is difficult to recycle the fine powders generated in the processes of demolition of concrete and manufacture of recycled aggregate because these powders may contain heavy metals exceeding the soil environmental standard, and such powders are disposed finally. It is well known that heavy metals are easily adsorbed on cement hydrates. To promote the total recycling of demolished concrete, it is important to remove adsorbed heavy metals from the fine powders easily. This article tried to gain a foothold in an effective method to separate heavy metals from cement hydrates easily. In this article, adsorption and desorption tests and a tank test was performed to investigate the desorption property as well as the leaching properties of heavy metals from cement hydrates in various chloride solutions. In this test, $\mathrm{Pb}$ was focused on as a heavy metal because relatively high amount of $\mathrm{Pb}$ is contained in recycled aggregates. Cement pastes containing $\mathrm{Pb}$ were prepared by adding $1 \% \mathrm{~Pb}\left(\mathrm{NO}_{3}\right)_{2}$ relative to cement by mass. About 20 mass $\%$ of potassium chloride, sodium chloride, and calcium chloride solutions were used as chloride solutions. The leachant solution was totally changed at certain periods, and the concentration of $\mathrm{Pb}$ in the collected leachant solution was measured. As a result, when cement pastes containing $\mathrm{Pb}$ were immersed in calcium chloride solution, a large number of $\mathrm{Pb}$ were leached out of cement pastes, while the leaching ratio of $\mathrm{Pb}$ in the specimen was less than $1 \%$ and almost the same for specimens immersed in deionized water, potassium chloride solution, and sodium chloride solution. From the results of desorption tests carried out in parallel, it is considered that the increase in $\mathrm{Pb}$ desorption caused the increase in $\mathrm{Pb}$ leaching from cube specimens. The leaching properties of $\mathrm{Pb}$ ions in chloride solutions could be influenced by the type of cation. These results show that the immersion of demolished concrete in calcium chloride solution may be used as an easy separation method of heavy metals from concrete.
\end{abstract}

\section{INTRODUCTION}

After the demolition of concrete structures, it is expected to recycle the whole of the demolished concrete. As of now, however, it is difficult to recycle the fine powders generated in the processes of demolition of concrete and manufacture of recycled aggregate because these powders may contain heavy metals exceeding the soil environmental standard. It has been reported that for roadbed material produced from demolished concrete, the dissolved amount of hexagonal chromium may exceed the soil environmental standard in Japan (Kuroda \& Konishi, 2010).

It is well known that heavy metals are easily adsorbed on cement hydrates (Takahashi, Kaita, \& Hasegawa, 1973). The interactions of metal ions with the hydrous oxide surfaces have been studied while the high $\mathrm{pH}$ conditions and various cement components make the fixation mechanisms extremely complex. There are several observations in regard to the fixation of metals. In strong basic solution such as pore solution of cement pastes, a lead ion could form the plumbite ion, $\mathrm{PbO}_{2}{ }^{2-}$, which should restrict adsorption on the surface of hydration products electronically because oxides of $\mathrm{C}-\mathrm{S}-\mathrm{H}$ have negative charges at high $\mathrm{pH}$. However, in fact, cement hydrates apparently adsorb $\mathrm{Pb}$ for some reasons (Kawai, Tano, Ishida, \& Sakanaka, 2006); therefore $\mathrm{Pb}$ may form cluster ions such as $\left[\mathrm{Pb}_{6} \mathrm{O}(\mathrm{OH})_{6}\right]^{4+}$, and these cations may precipitate as sulfates and/or may adsorb to the surface of hydration products with negative charges (Cocke \& Mollah, 1993).

As for the reactions of $\mathrm{Pb}^{2+}, \mathrm{Cd}^{2+}, \mathrm{Mn}^{2+}, \mathrm{Zn}^{2+}, \mathrm{Cu}^{2+}$, $\mathrm{Mg}^{2+}, \mathrm{Co}^{2+}$, or $\mathrm{Ni}^{2+}$ with calcium silicates (such as tobermorite, xonolite, and wollastonite), $\mathrm{Pb}^{2+}, \mathrm{Cd}^{2+}$, $\mathrm{Mn}^{2+}, \mathrm{Zn}^{2+}, \mathrm{Cu}^{2+}$, and $\mathrm{Mg}^{2+}$ appear to replace surface $\mathrm{Ca}^{2+}$, but it is difficult to delineate this reaction from precipitation reactions producing hydroxides, hydroxyl carbonates, or carbonates and from the double decomposition reaction with calcite, which is present as an impurity (Komarneni, Breval, \& Roy, 1988) In addition to the above chemical fixation mechanisms, it is indicated that $\mathrm{Pb}$ is located on the outer surface of cement clinker particles forming precipitation on setting process of cement, but the state of the precipitation is not clear (Cocke, McWhinney, Dufner, Horrell, \& Ortego, 1989; Ortego, Jackson, Yu, McWhinney, \& 
Cocke, 1989). As described above, heavy metals are fixed in cement matrix, and cement hydrates themselves adsorb heavy metals. To promote the total recycling of demolished concrete, it is important to easily remove adsorbed heavy metals from the fine powder, which mainly contain cement powders. This study tried to gain a foothold in an effective method to separate heavy metals from cement hydrates easily.

In this article, adsorption and desorption tests using powder specimens were performed to investigate desorption properties of heavy metals from cement hydrates in various chloride solutions.

In addition to the above tests, a tank test using cube specimens was carried out, and relationships between desorption properties of heavy metal in chloride solutions and leaching behavior of heavy metal were investigated. In this test, $\mathrm{Pb}$ was focused on as a heavy metal because relatively high amount of $\mathrm{Pb}$ is contained in recycled aggregates.

\section{EXPERIMENTS}

\subsection{Materials}

Cement paste specimens measuring $40 \mathrm{~mm} \mathrm{x}$ $40 \mathrm{~mm} \times 160 \mathrm{~mm}$ were prepared in this article. The water-cement ratios for the cement paste were 0.40 for the adsorption and desorption tests and 0.50, 0.60, and 0.65 for the tank test. The adsorption and desorption tests were carried out with a comparatively low watercement ratio to emphasize the characteristics of cement adsorptivity and desorptivity, while the tank test was performed with comparatively high watercement ratios to easily leach $\mathrm{Pb}$ from the cement paste. Ordinary Portland cement and deionized water were used as the cement and the mixing water, respectively. The chemical composition of the cement is shown in Table 1. In the tank test, cement pastes containing $\mathrm{Pb}$ were prepared by adding $1 \% \mathrm{~Pb}\left(\mathrm{NO}_{3}\right)_{2}$ relative to cement by mass in mixing water. The cement pastes were sealed and cured at $20^{\circ} \mathrm{C}$ for 28 days before the above tests.

Table 1. Chemical composition of cement.

\begin{tabular}{cccccccccc}
\hline \multicolumn{8}{c}{ Chemical composition (\%) } \\
\hline LOI & $\mathrm{SiO}_{2}$ & $\mathrm{Al}_{2} \mathrm{O}_{3}$ & $\mathrm{Fe}_{2} \mathrm{O}_{3}$ & $\mathrm{CaO}$ & $\mathrm{MgO}$ & $\mathrm{SO}_{3}$ & $\mathrm{Na}_{2} \mathrm{O}$ & $\mathrm{K}_{2} \mathrm{O}$ & $\mathrm{Cl}$ \\
\hline 1.75 & 20.82 & 5.15 & 2.92 & 64.69 & 1.12 & 2.22 & 0.23 & 0.38 & 0.005 \\
\hline
\end{tabular}

\subsection{Adsorption test}

After curing, hydrated cement pastes were pulverized to less than $600 \mathrm{~mm}$ before the adsorption test. Lead ions were dealt with as a heavy metal, and lead (II) nitrate solution was used as the heavy metal solution.

One gram of hydrated cement paste powder was added in $20 \mathrm{~mL}$ of deionized water and was stirred for $10 \mathrm{~h}$ in closed containers. After that, $1 \mathrm{~mL}$ of solution containing a certain concentration of lead ions was added and then stirred for another $6 \mathrm{~h}$. In this test, $0.5,1,2,4,8,10,12,16,20$, and $25 \mathrm{~g} / \mathrm{L}$ of lead ions were used as heavy metal solutions. After stirring, the solution was filtered with a membranefilter, and the concentration of heavy metal ions in the solution was determined with an atomic absorption spectrophotometer.

\subsection{Desorption test}

\section{(a) Desorption test with deionized water}

The residue remaining after filtration in the adsorption test and deionized water was used in this test. In addition, the residue used was obtained from filtration of solution containing every concentration of lead ions in the adsorption test. The residue was added to deionized water such that the liquid/solid substance ratio was 20 and was stirred for $10 \mathrm{~h}$. After stirring, the solution was filtered with a membrane-filter, and the concentration of $\mathrm{Pb}$ in the solution was determined with an atomic absorption spectrophotometer.

\section{(b) Desorption test with chloride solutions}

The residue remaining after filtration in the adsorption test and chloride solutions were used in this test. In addition, the residue used was obtained from filtration of solution containing $1 \mathrm{~mL}$ of $10,12,16,20$, and $25 \mathrm{~g} / \mathrm{L}$ of lead ions that was stirred for $6 \mathrm{~h}$ in the adsorption test. $\mathrm{NaCl}, \mathrm{KCl}$, and $\mathrm{CaCl}_{2} \cdot 2 \mathrm{H}_{2} \mathrm{O}$ solutions were dealt with chloride solutions, and the concentrations of each chloride solution were 1,3 , and 10 mass $\%$. Only when the solution was $\mathrm{CaCl}_{2} \cdot 2 \mathrm{H}_{2} \mathrm{O}$ solution, $20,25,30,35$, 40 , and 45 mass $\%$ of $\mathrm{CaCl}_{2} \cdot 2 \mathrm{H}_{2} \mathrm{O}$ solutions were also used. The residue was added to chloride solutions such that the liquid/solid substance ratio was 20 and was stirred for $10 \mathrm{~h}$. After stirring, the solution was filtered with a membrane-filter and the concentration of $\mathrm{Pb}$ in the solution was determined with an atomic absorption spectrophotometer.

\subsection{Tank test}

After curing, a cement paste specimen containing $\mathrm{Pb}$ was cut into a piece $40 \mathrm{~mm} \times 40 \mathrm{~mm} \times 40 \mathrm{~mm}$ in size and placed in a tank filled with leachant solution. Deionized water and $20 \%$ of $\mathrm{CaCl}_{2} \cdot 2 \mathrm{H}_{2} \mathrm{O}$ solution, $\mathrm{NaCl}$ solution, and $\mathrm{KCl}$ solution were used as the leachant solution. The leachant volume was $480 \mathrm{~mL}$, which equated to $5 \mathrm{~mL}$ per $100 \mathrm{~mm}^{2}$ of the specimen surface area; this is the leachant solution-to-specimen ratio specified in the JSCE (Japan Society of Civil Engineers) standards (JSCE, 2005). The liquid/solid substance ratios in this case range from 3.8 to $4.5(\mathrm{~mL} / \mathrm{g})$. The tank was capped to avoid water loss and carbonation of the specimen. The leachant solution was totally changed at the periods of, $0.25,1,2.25,4,9,16,25$, and 36 days. The $\mathrm{Pb}$ concentration in the leachant solutions 
collected at the above periods was determined with an atomic absorption spectrophotometer.

\section{RESULTS}

\subsection{Adsorption test}

The adsorption isothermal curve of lead ions for cement pastes is shown in Figure 1. It is found that the adsorption isothermal curve for $\mathrm{Pb}$ and cement hydrates can be approximated by the Freundlich isotherm equation represented as Equation (1) (Kawai et al., 2006). For the specimens in this test, the isothermal curve can also be classified into the Freuindlich equation represented in Eq. (2)

$$
\begin{aligned}
& V=a C^{1 / n} \\
& V=1.82 C^{1 / 1.39}
\end{aligned}
$$

where $V$ is the amount of adsorption, $C$ is the equilibrium concentration, and $a$ and $n$ are constants given for adsorbate and adsorbent at a particular temperature.

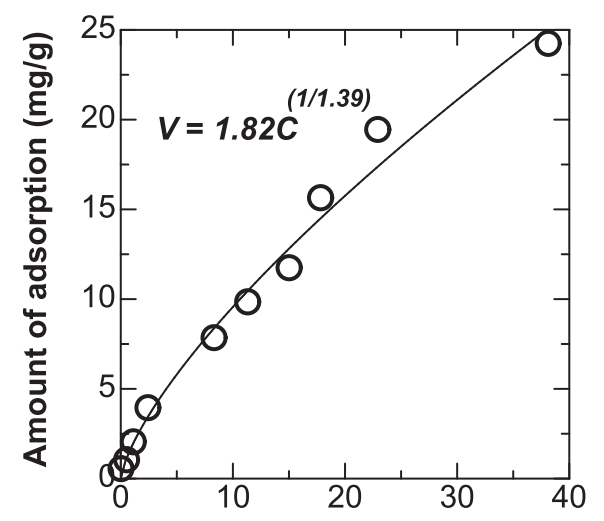

Equilibrium concentration ( $\mathrm{mg} / \mathrm{l})$

Figure 1. Adsorption test; the adsorption isothermal curve.

\subsection{Desorption test}

(a) Desorption test with deionized water

Figure 2 shows the relationship between the adsorption amount and the desorption amount. In addition, Figure 3 shows the relationship between each equilibrium concentration of $\mathrm{Pb}$ and the amount of adsorption after the adsorption test and the desorption test. Figure 2 shows a linear relationship between the initial adsorption amount and the desorption amount. The slope of the approximate line was 0.021 , which implies that almost $2 \%$ of adsorbed lead ions were desorbed from cement hydrates in proportion to the adsorption amount. On the contrary, in the previous study, adsorption of $\mathrm{Pb}$ by cement hydrates depended on the surface area of $\mathrm{C}-\mathrm{S}-\mathrm{H}$, and decomposition of $\mathrm{C}-\mathrm{S}-\mathrm{H}$ caused by carbonation resulted in the change of adsorption amount of $\mathrm{Pb}$ (Sato, Miyamoto, \& Kawai, 2008).

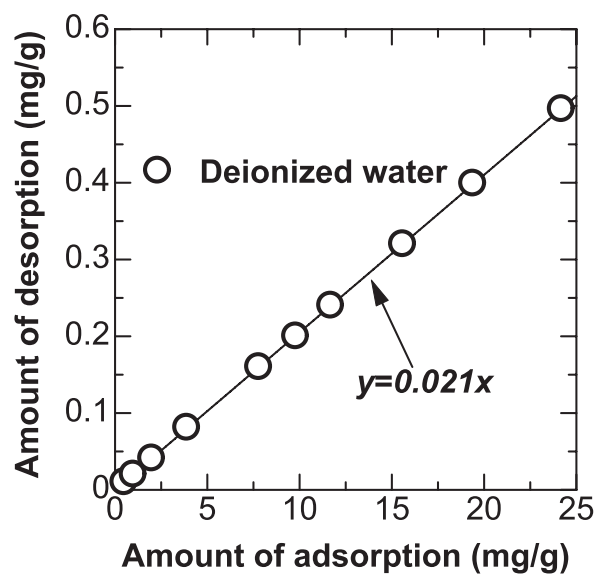

Figure 2. Relation between the adsorption and desorption amounts.

However, Figure 3 shows the isothermal curves after the adsorption test and the desorption test, and there is little or no difference between both curves. This result indicates that decomposition of cement hydrates resulting in affecting adsorption and desorption properties did not occur at least during $10 \mathrm{~h}$ desorption process in this test. From the above, it is thought that $\mathrm{Pb}$ adsorbed on fine cement hydrates barely desorbed into deionized water.

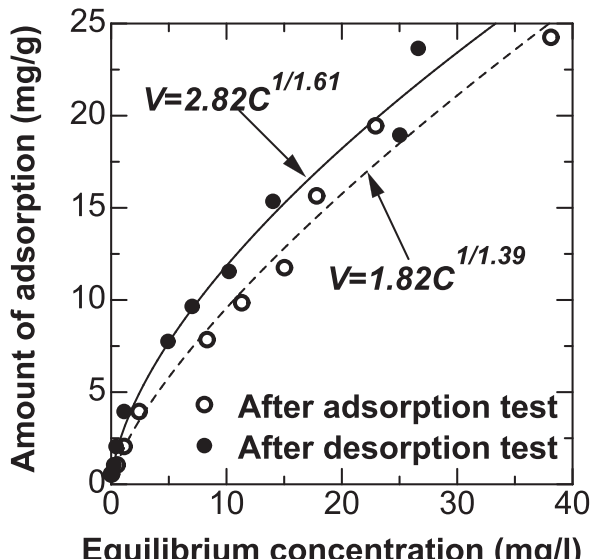

Figure 3. Adsorption amounts after adsorption and desorption tests.

(b) Desorption test with chloride solutions

Figures 4, 5, and 6 show the relationship between the adsorption amount and the desorption amount of each concentration of $\mathrm{NaCl}, \mathrm{KCl}$, and $\mathrm{CaCl}_{2} \cdot 2 \mathrm{H}_{2} \mathrm{O}$ solutions, respectively. Figure 7 shows the comparison of the desorption amount among four chloride solutions. The initial adsorption amount for each solution is about $24 \mathrm{mg} / \mathrm{sample} \mathrm{g}$.

From Figure 4, a linear relationship can be seen between the initial adsorption amount and the desorption amount for $\mathrm{NaCl}$ solution, such as in the case of deionized water. In addition, the desorption 
amount was about $1-2 \%$ of the initial adsorbed amount for each concentration, although the desorption amount differed slightly between the concentrations of the solution. The results for $\mathrm{KCl}$ solutions shown in Figure 5 are also similar to the result for $\mathrm{NaCl}$ solution, and the magnitude of the desorbed amount itself was very low in $\mathrm{NaCl}$ and $\mathrm{KCl}$ solutions. From the slopes of the regression lines in the figures, the desorption amounts relative to the adsorption amounts for $\mathrm{NaCl}$ and $\mathrm{KCl}$ solutions are 0.79 to $2.7 \%$ and 1.9 to $2.2 \%$, respectively.

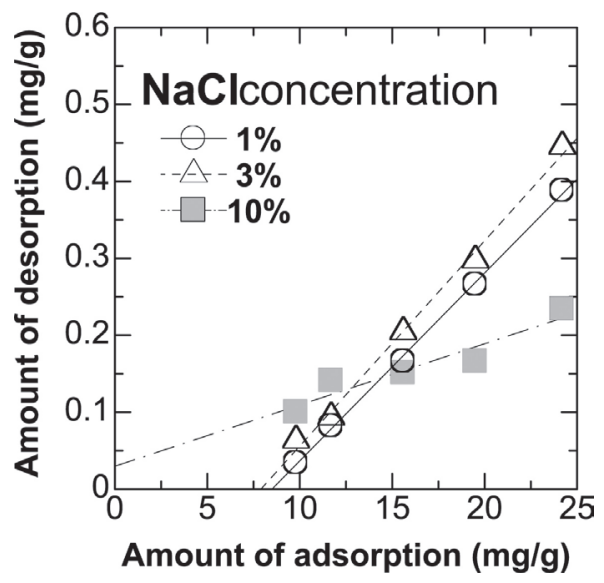

Figure 4. Amount of desorption in $\mathrm{NaCl}$ solution.

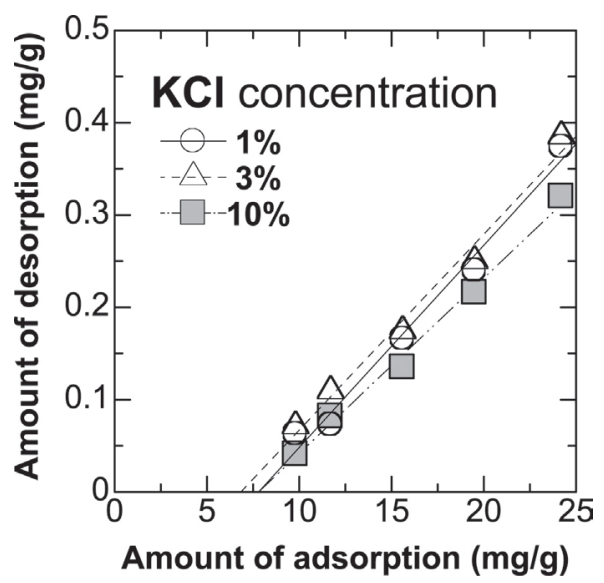

Figure 5. Amount of desorption in $\mathrm{KCl}$ solution.

On the contrary, Figures 6 and 7 show that the desorption amount of $\mathrm{Pb}$ is about $4 \%$ of the initial adsorption amount for 1 and $3 \%$ of $\mathrm{CaCl}_{2} \cdot 2 \mathrm{H}_{2} \mathrm{O}$ solution, and a little larger than for the other solutions. Furthermore, the desorption amount increased to $20 \%$ of the initial adsorption amount for $10 \%$ of $\mathrm{CaCl}_{2} \cdot 2 \mathrm{H}_{2} \mathrm{O}$ solution, and the different tendency with the other chloride solutions was observed. These results indicate that $\mathrm{CaCl}_{2}$ accelerates the desorption of $\mathrm{Pb}$. $\mathrm{CaCl}_{2}$ is often used as a deicing salt. If concrete is exposed to an environment of concentrated $\mathrm{CaCl}_{2}$, a significant quantity of $\mathrm{Pb}$ could be leached out.

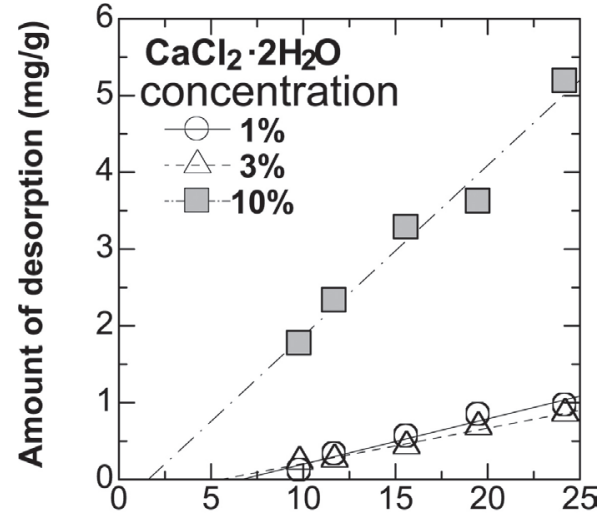

Amount of adsorption $(\mathrm{mg} / \mathrm{g})$

Figure 6. Amount of desorption in $\mathrm{CaCl}_{2}$ solution.

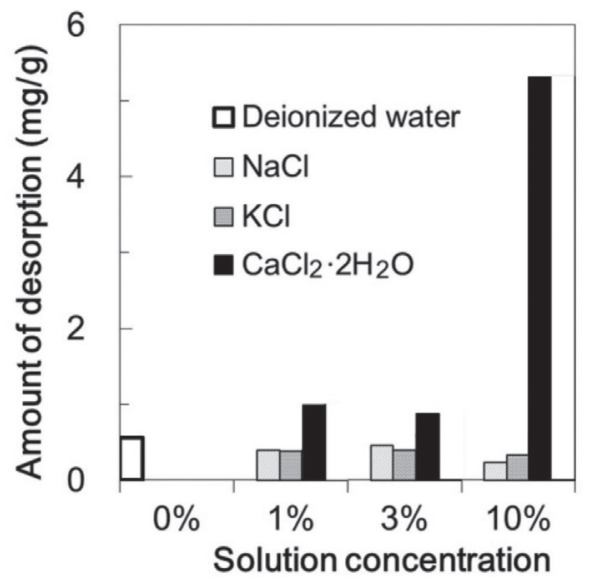

Figure 7. Amount of desorption in each solution.

The desorption test with $20,25,30,35,40$, and $45 \%$ of $\mathrm{CaCl}_{2} \cdot 2 \mathrm{H}_{2} \mathrm{O}$ solutions was carried out to understand the maximum desorption ratio (the ratio of the desorption amount to the initial adsorption amount) of $\mathrm{Pb}$. Figure 8 shows the relationship between the desorption amount and the initial adsorption amount for each concentration of the solution. The five lines in Figure 8 represent the desorption ratio. The desorption ratio for each line is $80,70,60,50$, and $40 \%$. The desorption ratio of $\mathrm{Pb}$ increased with the increase in the concentration of the solution within the range of the concentration from 20 to $40 \%$. The desorption ratio was maximum when $40 \%$ of $\mathrm{CaCl}_{2} \cdot 2 \mathrm{H}_{2} \mathrm{O}$ solution was used, and the value of the desorption ratio was over $70 \%$. In addition, the desorption ratio for $4 \%$ of $\mathrm{CaCl}_{2} \cdot 2 \mathrm{H}_{2} \mathrm{O}$ solution was about the same as that for $40 \%$ of $\mathrm{CaCl}_{2} \cdot 2 \mathrm{H}_{2} \mathrm{O}$ solution.

Cocke (1990) showed that $\mathrm{Pb}$ is incorporated into the cement matrix by adsorption onto $\mathrm{C}-\mathrm{S}-\mathrm{H}$, and Bishop (1988) showed that $\mathrm{Pb}$ precipitates as a lead silicate; however, crystalline $\mathrm{Pb}$-combounds could not be detected with an X-ray diffraction (XRD) analysis. Supposing that $\mathrm{Pb}$ incorporated into the cement matrix exists as $\mathrm{Pb}$-compounds as well as $\mathrm{PbCl}_{2}$ were 
generated during the stirring process in the $\mathrm{CaCl}_{2}$ solution, the reaction could be delineated as follows.

$\mathrm{Pb}$-compounds $+\mathrm{CaCl}_{2} \rightarrow \mathrm{PbCl}_{2}+\mathrm{Ca}$-compounds (3)

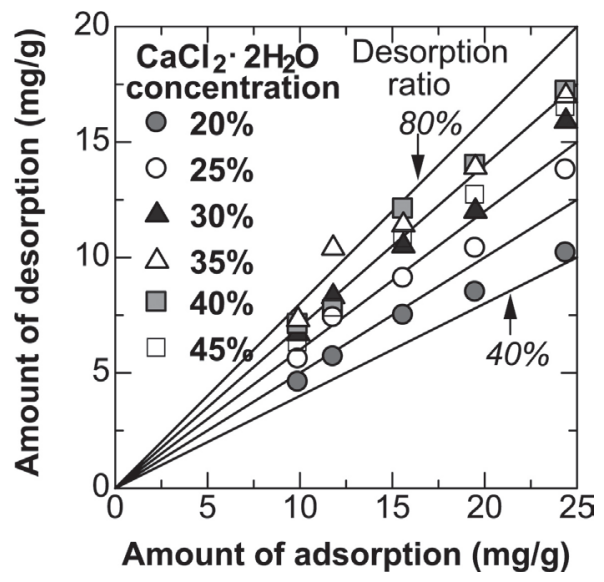

Figure 8. Amount of desorption in $\mathrm{CaCl}_{2}$ solution.

The above reaction would be possible because the solubility of $\mathrm{PbCl}_{2}$ and Ca-compounds should be much lower than $\mathrm{CaCl}_{2}$. However, the desorbed amounts for $20-45 \% \mathrm{CaCl}_{2} \cdot 2 \mathrm{H}_{2} \mathrm{O}$ solutions are much higher than that for the $10 \% \mathrm{CaCl}_{2} \cdot 2 \mathrm{H}_{2} \mathrm{O}$ solution, and other desorption mechanisms may take place in these solutions.

\subsection{Tank test}

A tank test was carried out using deionized water, $\mathrm{NaCl}$ solution, and $\mathrm{KCl}$ solution as leachants. The relationships between leaching duration and cumulative leaching concentration were shown in Figures 9-11. The vertical axis in the figure represents the leaching amount of $\mathrm{Pb}$ for unit mass of the specimen. When specimens immersed in deionized water, the least amount of $\mathrm{Pb}$ was leached out, and the cumulative leaching amount of $\mathrm{Pb}$ at 36 days corresponded to approximately $0.1 \%$ of total amount of $\mathrm{Pb}$ contained in the specimen. When chloride solutions were used as leachants, leaching amount of $\mathrm{Pb}$ from specimens in $\mathrm{NaCl}$ solution and $\mathrm{KCl}$ solution was a little larger than that from specimens in deionized water.

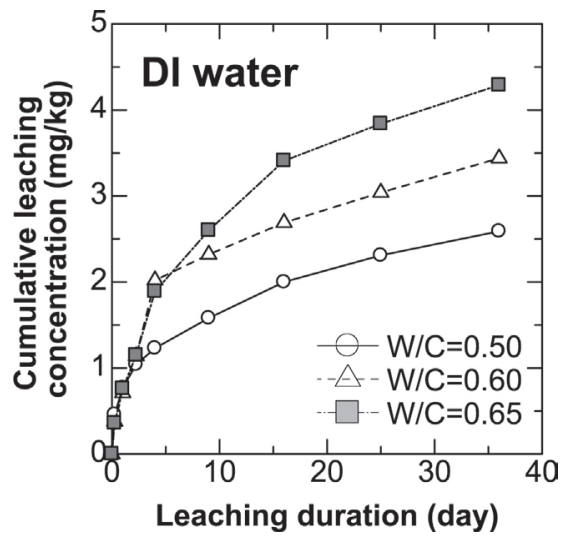

Figure 9. Amount of leaching in Deionized water.

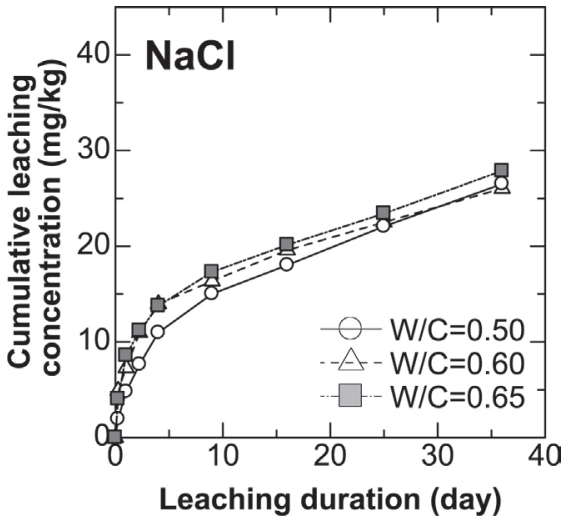

Figure 10. Amount of leaching in $\mathrm{NaCl}$ solution.

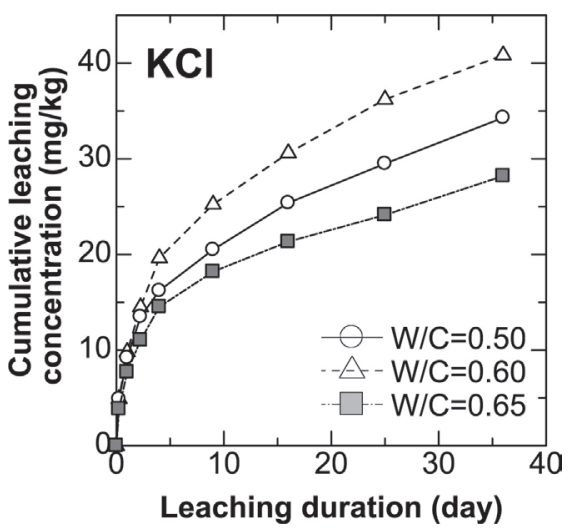

Figure 11. Amount of leaching in $\mathrm{KCl}$ solution.

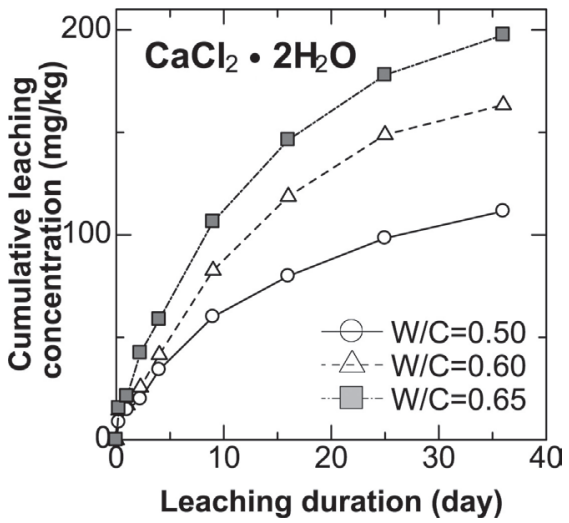

Figure 12. Amount of leaching in $\mathrm{CaCl}_{2}$ solution.

On the contrary, as shown in Figure 12, significantly large amount of $\mathrm{Pb}$ was leached out from the specimen in $\mathrm{CaCl}_{2}$ solution, and the cumulative leaching amount of $\mathrm{Pb}$ at 36 days corresponded to $2.7-5.2 \%$ of total amount of $\mathrm{Pb}$ contained in the specimen. This tendency of $\mathrm{Pb}$ leaching from these cube specimens in the above solutions was similar to the results of the desorption tests using powder specimens. Therefore, the increase in $\mathrm{Pb}$ leaching from the cube specimen in $\mathrm{CaCl}_{2}$ solution was associated with the desorption.

Figures 13-16 represent the same results as Figures 9-12, but horizontal axis represents the root of the day 
on which the leachant was replaced. In the tank test, supposing that $\mathrm{Pb}$ leaching was governed by diffusion, the leaching amount is proportional to the square root of the time. In this article, the relationship between the cumulative leaching concentration and the square root of the time was approximated by two linear lines. Comparing with the gradient of the approximate line before 3 days (the value of about 1.73 in Figures 13-16), the gradient of approximate line after 3 days decreases when specimens were immersed in deionized water, $\mathrm{NaCl}$ solution, and $\mathrm{KCl}$ solution, while the gradient increases only when specimens were immersed in $\mathrm{CaCl}_{2}$ solution. Considering this result and the results of desorption tests, it is implied that $\mathrm{CaCl}_{2}$ penetrating into the specimen accelerated the desorption of $\mathrm{Pb}$ from cement hydrates, which resulted in the increase in the concentration of $\mathrm{Pb}$ in pore solution as well as the increase in leaching amount. The cumulative leaching amount of the specimens immersed in $\mathrm{NaCl}$ solution and $\mathrm{KCl}$ solution was also larger than that of the specimen immersed in deionized water. However, $\mathrm{Pb}$ leaching from these specimens is independent of the water-cement ratio, and the gradient after 3 days decreases. Therefore, it is thought that the reason why the leaching amount in $\mathrm{NaCl}$ and $\mathrm{KCl}$ solutions became larger than in deionized water is different from desorption.

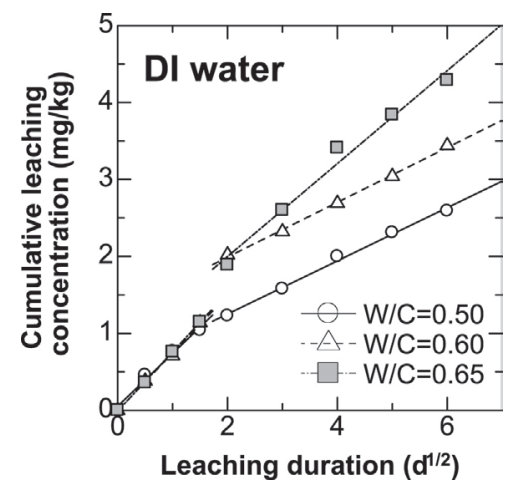

Figure 13. Amount of leaching in deionized water (x-axis: square root of leaching duration).

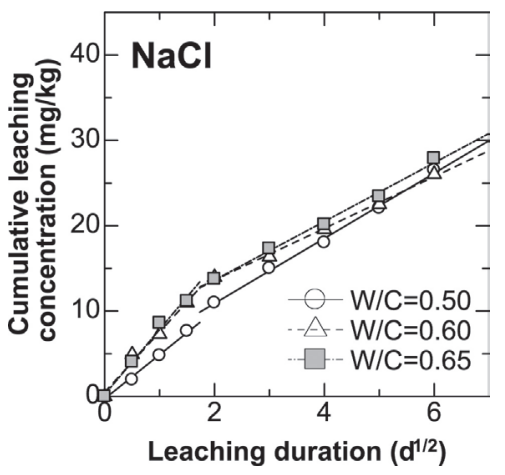

Figure 14. Amount of leaching in $\mathrm{NaCl}$ solution.

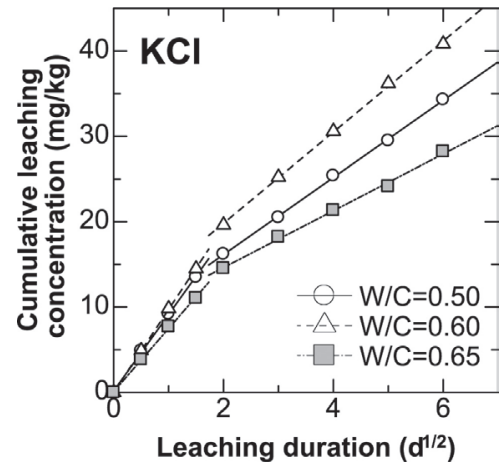

Figure 15. Amount of leaching in $\mathrm{KCl}$ solution.

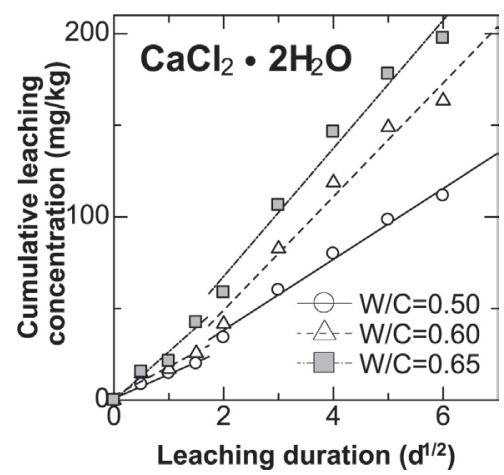

Figure 16. Amount of leaching in $\mathrm{CaCl}_{2}$ solution.

\section{CONCLUSIONS}

1. The desorption amount is about $1-2 \%$ of the initial adsorbed amount for 1, 3, and $10 \%$ of $\mathrm{NaCl}$ and $\mathrm{KCl}$ solutions and deionized water. The desorption amount of $\mathrm{Pb}$ is about $4 \%$ of the initial adsorption amount for 1 and $3 \%$ of $\mathrm{CaCl}_{2} \cdot 2 \mathrm{H}_{2} \mathrm{O}$ solution, and the desorption amount increased to $20 \%$ of the initial adsorption amount for $10 \%$ of $\mathrm{CaCl}_{2} \cdot 2 \mathrm{H}_{2} \mathrm{O}$ solution.

2. The desorption ratio of $\mathrm{Pb}$ increases with the increase in the concentration of $\mathrm{CaCl}_{2} \cdot 2 \mathrm{H}_{2} \mathrm{O}$ solution within the range of the concentration from 20 to $40 \%$. When $40 \%$ of $\mathrm{CaCl}_{2} \cdot 2 \mathrm{H}_{2} \mathrm{O}$ solution was used, the desorption ratio was maximum and was about $70 \%$.

3. Pb leaching from cement pastes were accelerated drastically when cement pastes was immersed in $\mathrm{CaCl}_{2}$ solution. The cumulative leaching amount of $\mathrm{Pb}$ at $36 \mathrm{~d}$ corresponded to $2.7-5.2 \%$ of total amount of $\mathrm{Pb}$ contained in the specimen.

\section{REFERENCES}

Bishop, P. L. (1988). Leaching of inorganic hazardous constituents from stabilized/solidified hazardous wastes. Hazardous Waste and Hazardous Materials, 5(2), 129-143. 
Cocke, D. L. (1990). The binding chemistry and leaching mechanisms of hazardous substances in cementitious solidification/stabilization systems. Journal of Hazardous Masterials, 24(2-3), 231-253.

Cocke, D. L., \& Mollah, M. Y. A. (1993). The chemistry and leaching mechanisms of hazardous substances in cementitious solidification/ stabilization systems. In R. D. Spence (Ed.), Chemistry and microstructure of solidified Waste Forms (pp. 187-242). Boca Raton, FL: CRC Press.

Cocke, D. L., McWhinney, H. G., Dufner, D. C., Horrell, B., \& Ortego, J. D. (1989). An XPS and EDS investigation of Portland cement doped with $\mathrm{Pb}(\mathrm{II})$ and $\mathrm{Cr}(\mathrm{III})$ cations. Hazadous Waste and Hazardous Materials, 6(3), 251-267.

JSCE (Japan Society of Civil Engineers). (2005). Test method for leaching of trace elements from hardened concrete. JSCE Standards (JSCE-G575).

Kawai, K., Tano, S., Ishida, T., \& Sakanaka, K. (2006). A study on mechanism of heavy metal leaching from concrete. Cement Science and Concrete Technology, 60, 314-321. . (in Japanese).
Komarneni, S., Breval, E., \& Roy, D. M. (1988). Reactions of some calcium silicates with metal cations. Cement and Concrete Research, 18(2), 204-220.

Kuroda, Y., \& Konishi, N. (2010). Leaching of hexavalent chromium from crushed concrete. Journal of Structural and Construction Engineering, 74(646), 2155-2161. . (in Japanese).

Ortego, J. D., Jackson, S., Yu, G.-S., McWhinney, H. G., \& Cocke, D. L. (1989). Solidification of hazardous substances - A TGA and FTIR study of portland cement containing metal nitrates. Jounal of Environmental Science and Health, 24(6), 589-602.

Sato, T., Miyamoto, Y., \& Kawai, K. (2008). Influence of carbonation on heavy metal leaching from cement hydrates. Proceedings of Annual Meeting of JSCE Chugoku Branch, 60(5), V-32. (in Japanese).

Takahashi, H., Kaita, E., \& Hasegawa, S. (1973). Fundamental study on cement solidification of industrial wastes containing heavy metals. Proceedings of Japan Cement Association, 27, 91-95. . (in Japanese). 